\title{
Effect of Spacing on Different Growth Parameters and Oil Content of Ocimum basilicum L under Temperate Conditions of Kashmir Valley
}

\author{
Huzaifa Majeed ${ }^{1}$, G. M. Bhat ${ }^{1 *}$, M. A. Islam ${ }^{1}$, T. A. Rather ${ }^{1}$, \\ F. A. Shah khan ${ }^{2}$, Rayees A. Bhat ${ }^{1}$ and Nida Rafiq ${ }^{1}$ \\ ${ }^{1}$ Faculty of Forestry, Sher-e-Kashmir University of Agricultural Sciences \& Technology of \\ Kashmir, Benihama Ganderbal Campus (UT of J\&K), India \\ ${ }^{2}$ High Mountain arid agriculture research institute Stakna, SKUAST-K, Leh, India \\ *Corresponding author
}

\section{A B S T R A C T}

\section{Keywords}

Basil, Essential oil, Transplant bed, Ocimum, Survival

Article Info

Accepted:

10 September 2020

Available Online:

10 October 2020
The present study on out planting performance of Ocimum basilicum in field plantation was undertaken to optimize the spacing required for achieving maximum yield and essential oil. Seeds collected locally were sown in a broadcast manner and transplanted later at seedling stage at different spacing viz., $S_{1}(10 \mathrm{~cm} \times 10 \mathrm{~cm}), S_{2}(10 \mathrm{~cm} \times 20 \mathrm{~cm}), S_{3}$ $(10 \mathrm{~cm} \times 30 \mathrm{~cm})$ and $S_{4}(10 \mathrm{~cm} \times 40 \mathrm{~cm})$. Seeds were sown in well prepared nursery beds in March, 2018. Germination started from 6th days of sowing and was completed within 15 days. All the germinated seeds survived in open nursery beds during the first growing season. Growth parameters like plant height, No. of leaves per plant, leaf fresh weight $\mathrm{g} /$ plant, leaf dry weight $\mathrm{g} / \mathrm{plant}$, above ground biomass $\mathrm{g} / \mathrm{plant}$, below ground biomass $\mathrm{g} / \mathrm{plant}$ and total biomass g/plant showed an increasing trend with the decrease in spacing. Among the four spacing the maximum total biomass $(27.76 \mathrm{~g} / \mathrm{plant})$ was registered in spacing $\mathrm{S}_{1}(10 \mathrm{~cm} \times 10 \mathrm{~cm})$ and minimum $(14.10 \mathrm{~g} / \mathrm{plant})$ was recorded at the higher spacing $\mathrm{S}_{4}(10 \mathrm{~cm} \times 40 \mathrm{~cm})$. Maximum average seed oil $(0.0105 \mathrm{ml} / \mathrm{plant})$ and herbage oil $(0.532 \mathrm{ml} /$ plant $)$ was recorded in the spacing $\mathrm{S}_{1}(10 \mathrm{~cm} \times 10 \mathrm{~cm})$.

\section{Introduction}

Basil is a member of tropical genus Ocimum. It is native to tropical parts of Asia, Africa, Central and South America, but has now become globalized due to human cultivation. Basil is a member of the Lamiaceae, used both as a culinary and ornamental herb. Sweet basil (Ocimum basilicum L.) is an annual, aromatic, herbal plant, belonging to the Lamiaceae family. It comes from the tropical regions of South-Eastern Asia and it is grown in many countries of the world as an ornamental, seasoning and medicinal plant. The aim of basil growing is to obtain good herb yield with substantial contents of essential oil, the main biologically active substance. Basil has shown antioxidant and antimicrobial activities due to its phenolic and aromatic compounds. The main phenolics reported in basil are phenolic acids and flavonol-glycosides (Yayasinghe et al., 2003). Basil is traditionally used worldwide as a medicinal herb to treat numerous ailments. 
The leaves and flowering parts are traditionally used as antispasmodic, aromatic, carminative, and digestive remedies, and to treat abdominal cramps, gastroenteritis, fever, poor digestion, nausea, migraines, insomnia, depression and dysentery. They have been applied externally to treat acne, insect stings, snake bites, and skin infections (Venancio et al., 2011; Bora et al., 2011Basil was sacred to the gods in India, Krishna and Vishnu. In America where basil has been grown for over 200 years, the plant was originally air-dried or preserved in layers of salt and kept in earthenware crocks. Commercially, three major types of basil with essential oil or dried leaves as the end product are used. French basil, reputed to be sweetest in flavor and darkest in color, is the most valued. American basil, noted for rich color, sweet flavor, cleanliness, and uniformity of particle size, is considered to be of high quality. Paton and Putievsky (1996) studied the industrial production of sweet basil. The seed production was performed in controlled conditions. In essential oil-containing plants the chemicals are sometimes more important characteristics than morphological features, which alone are inadequate to describe the taxon. Therefore, the chemotype have to be determined before the plant is used for industrial purposes.

Sadeghi et al., (2009) studied the effect of plant-density and sowing-date on yield of basil (Ocimum basilicum L.) in Iran. Result showed that seed yield was influenced by sowing date and plant density interaction. Early sowing date resulted in higher seed yields as evident from higher aboveground biomass, the number of umbrella per plant, the number of seed per umbrella and plant height. Harvest index and 1000 seed weight was not affected by sowing date and planting density. Earlier sown plants with density of $200 \mathrm{~m}^{-2}$ resulted in higher seed yields. Werker et al., (1993) reported great differences in the essential oil content and composition of young and mature leaves. Usually, young leaves had a higher content of essential oil per area unit compared to old leaves. As the leaf size increased, the essential oil content decreased. Javanmardi et al., (2002) reported that basil is known to have strong antioxidant activity and contains phenolic compounds such as rosmarinic acid, chicoric acid and caffeic acid, these phenolic compounds and flavonoids are strong antioxidants. keeping the multifarious uses of sweet basil in view, the present study was undertaken to to standardize propagation technique for Ocimum basilicum L. through seeds under field conditions and to estimate the oil content present in different parts of Ocimum basilicum L. by Hydro distillation.

\section{Materials and Methods}

Investigations conducted on "Effect of spacing on different growth parameters and oil content of Ocimum basilicum L under temperate conditions of Kashmir Valley." was carried out in the Faculty of Forestry, Sher-eKashmir University of Agricultural Sciences \& Technology of Kashmir, Benhama, Ganderbal (J\&K) situated at $34^{\circ} 16^{\prime} 44^{\prime \prime} \mathrm{N}$ and $74^{\circ} 46^{\prime} 31^{\prime \prime} \mathrm{E}$ at an elevation of $1783 \mathrm{~m}(5850$ feet) above mean sea level during 2018-2019. The study area is characterized by temperate climate experiencing four distinct seasons: a severe winter (December to February), a cold spring (March to May), a mild summer (June to August) and a pleasant autumn (September to November). The site falls in a mid to high altitude area characterized by hot summer and very cold winters. The study area received an annual rainfall of $694.4 \mathrm{~mm}$. The minimum temperature ranged from-3.98 to $16.61^{\circ} \mathrm{C}$ and maximum temperature from 9.84 to $30.43^{\circ} \mathrm{C}$ and the average maximum relative humidity from 73.27 to 93.97 percent, whereas the mean minimum relative humidity ranged from 38.42 to 68.97 percent during the study 
period. Seeds collected locally were sown in a broadcast manner in the month of March and transplanted later at seedling stage in transplant beds at different spacing viz., $S_{1}$ $(10 \mathrm{~cm} \times 10 \mathrm{~cm}), S_{2}(10 \mathrm{~cm} \times 20 \mathrm{~cm}), S_{3}(10$ $\mathrm{cm} \times 30 \mathrm{~cm})$ and $\mathrm{S}_{4}(10 \mathrm{~cm} \times 40 \mathrm{~cm})$. The following observations were recorded at the end of the growing season

Plant height was measured from bottom to tip of the plant by using a scale.

Number of leaves per plant was counted manually.

Leaf area $\left(\mathrm{cm}^{2}\right)$ was measured by leaf area meter.

Leaf fresh weight (kg) was taken after harvesting using a digital balance.

Leaf dry weight (g) was taken after shade drying till constant weight was achieved.

Above-ground biomass (g/plant) was taken after harvesting using top pan balance.

Below-ground biomass (g/plant):-After harvesting roots were weighed using top pan balance.

Total biomass (g/plant) was calculated by adding above ground biomass and below ground biomass.

Seed yield (g/plant) was obtained using a digital balance.

\section{Observations recorded in the laboratory}

Seed weight (1000 seeds) was obtained using a digital balance.

Germination percentage:-The germination percentage was calculated using following formula:

Germination percentage $=\frac{\text { No.ofseedsgerminated }}{\begin{array}{l}\text { Total no. of seeds } \\ \text { sown }\end{array}} \times 100$

Moisture percent:-The moisture percent was calculated using following formula:

$$
\text { Moisture content }=\frac{\text { Fresh weight }- \text { Dry weight }}{\text { Fresh weight }} \times 100
$$

\section{Estimation of oil Content of Ocimum basilicum $\mathbf{L}$.}

Estimation of oil content was done using Hydro distillation.

Total oil content in seeds:-Seeds collected from experimental plots were dried under shade and samples were subjected to hydro distillation.

Total oil content in Herbage (leaves, roots, stems and branches): Samples after being collected from the plots were dried in shade and subjected to hydro distillation.

Statistical analysis and interpretation: The data obtained was subjected to statistical analysis. The observed data was analyzed in MS Excel and statistical package for social sciences (SPSS) software for meaningful interpretation.

\section{Results and Discussion}

Seeds collected locally were sown in a broadcast manner and transplanted later at seedling stage at different spacing viz., $S_{1}(10$ $\mathrm{cm} \times 10 \mathrm{~cm}), S_{2}(10 \mathrm{~cm} \times 20 \mathrm{~cm}), S_{3}(10 \mathrm{~cm}$ $\times 30 \mathrm{~cm})$ and $S_{4}(10 \mathrm{~cm} \times 40 \mathrm{~cm})$. Seeds were sown in well prepared nursery beds in March. Germination started from 6th days of sowing and was completed by first week of April. All the germinated seeds survived in open nursery beds during the first growing season. Seeds sown in broadcast manner, germinated within 6-15 days and were transplanted after 8 weeks when they were $10-15 \mathrm{~cm}$ high. Seed germination in laboratory started from second day and was completed in 7 days, which indicated that the seeds did not had any kind of dormancy. Different growth parameters were recorded at the end of the first growing season in terms of survival percentage, plant height $(\mathrm{cm})$, number of leaves per plant, leaf area (using leaf area meter), leaf fresh weight 
(g/plant), leaf dry weight ( $\mathrm{g} / \mathrm{plant}$ ), above ground biomass (g/plant), below ground biomass (g/plant) and total biomass (g/plant). After subjecting the data to statistical analysis results are presented in tables 1-5. Growth and yield of herbal plants are closely connected with meteorological conditions and agrotechnical procedures (Azizi and Kahrizi, 2008; Acimovic, 2013). Although growth, yield and essential oil of medicinal plants are under control of genetic factors; however, these features are affected by the environmental factors too. Zaffaroni and Schneiter (1991) noted that three production variables that a producer can manipulate to influence the production of a given crop are plant population, row arrangement and hybrid selection. There are many factors that influence agronomic characteristics, biomass and essential oil yield of aromatic and medicinal plants. Among these plant spacing deserves special attention (Khazaie et al., 2007).

Table.1 Effect of spacing on different growth parameters of Ocimum basilicum

\begin{tabular}{|c|c|c|c|c|}
\hline Treatments & Survival (\%) & $\begin{array}{c}\text { Plant height } \\
(\mathbf{c m})\end{array}$ & $\begin{array}{c}\text { No. of } \\
\text { leaves/plant }\end{array}$ & $\begin{array}{c}\text { Leaf area } \\
\left(\mathbf{c m}^{\mathbf{2}}\right)\end{array}$ \\
\hline $\mathbf{S}_{\mathbf{1}}$ & 100 & 85.94 & 31 & 2.58 \\
\hline $\mathbf{S}_{\mathbf{2}}$ & 100 & 82.92 & 28 & 2.63 \\
\hline $\mathbf{S}_{\mathbf{3}}$ & 100 & 75.06 & 22.8 & 2.79 \\
\hline $\mathbf{S}_{\mathbf{4}}$ & 100 & 71.88 & 18.2 & 3.01 \\
\hline $\mathbf{C D} \mathbf{( P \leq \mathbf { 0 . 0 5 } )}$ & $\mathrm{NS}$ & 2.3 & 2.17 & 0.12 \\
\hline
\end{tabular}

Table.2 Effect of spacing on the leaf moisture content of Ocimum basilicum

\begin{tabular}{|c|c|c|c|}
\hline Treatments & $\begin{array}{c}\text { Leaf fresh weight } \\
\text { (g/plant) }\end{array}$ & $\begin{array}{c}\text { Leaf dry weight } \\
\text { (g/plant) }\end{array}$ & $\begin{array}{c}\text { Moisture content } \\
(\mathbf{\%})\end{array}$ \\
\hline $\mathbf{S}_{\mathbf{1}}$ & 7.67 & 3.83 & 50.06 \\
\hline $\mathbf{S}_{\mathbf{2}}$ & 5.27 & 2.63 & 50.09 \\
\hline $\mathbf{S}_{\mathbf{3}}$ & 3.16 & 1.54 & 51.26 \\
\hline $\mathbf{S}_{\mathbf{4}}$ & 1.8 & 0.9 & 50 \\
\hline $\mathbf{C D}(\mathbf{P} \leq \mathbf{0 . 0 5})$ & 1.87 & 0.93 & NS \\
\hline
\end{tabular}

Table.3 Effect of spacing on the seed yield per plant of Ocimum basilicum

\begin{tabular}{|c|c|c|c|}
\hline Treatments & $\begin{array}{c}\text { No. of umbrella } \\
\text { per plant }\end{array}$ & $\begin{array}{c}\text { No. of seeds per } \\
\text { plant }\end{array}$ & $\begin{array}{c}\text { Seed yield } \\
\text { (g/plant) }\end{array}$ \\
\hline $\mathbf{S}_{\mathbf{1}}$ & 30 & 603.2 & 1.056 \\
\hline $\mathbf{S}_{\mathbf{2}}$ & 29.2 & 581 & 1.02 \\
\hline $\mathbf{S}_{\mathbf{3}}$ & 27 & 566.8 & 0.992 \\
\hline $\mathbf{S}_{\mathbf{4}}$ & 26.4 & 557 & 0.974 \\
\hline $\mathbf{C D}(\mathbf{P} \leq \mathbf{0 . 0 5})$ & 1.692 & 12.858 & 0.023 \\
\hline
\end{tabular}


Table.4 Effect of spacing on the above ground biomass (AGB) per plant of Ocimum basilicum L.

\begin{tabular}{|c|c|c|c|c|}
\hline Treatments & $\begin{array}{c}\text { Seed yield } \\
\text { (g/plant) }\end{array}$ & $\begin{array}{c}\text { Leaf yield } \\
\text { (g/plant) }\end{array}$ & $\begin{array}{c}\text { Stem+ Branches } \\
\text { (g/plant) }\end{array}$ & $\begin{array}{c}\text { AGB } \\
\text { (g/plant) }\end{array}$ \\
\hline $\mathbf{S}_{\mathbf{1}}$ & 1.056 & 3.836 & 19.914 & 24.806 \\
\hline $\mathbf{S}_{\mathbf{2}}$ & 1.02 & 2.638 & 18.508 & 22.166 \\
\hline $\mathbf{S}_{\mathbf{3}}$ & 0.992 & 1.584 & 13.074 & 15.65 \\
\hline $\mathbf{S}_{\mathbf{4}}$ & 0.974 & 0.9 & 9.874 & 11.738 \\
\hline $\mathbf{C D}(\mathbf{P} \leq \mathbf{0 . 0 5})$ & 0.023 & 0.935 & 1.304 & 1.748 \\
\hline
\end{tabular}

Table.5 Effect of spacing on the Total Biomass per plant of Ocimum basilicum

\begin{tabular}{|c|c|c|c|}
\hline Treatments & BGB (g/plant) & AGB (g/plant) & $\begin{array}{c}\text { Total Biomass } \\
\text { (g/plant) }\end{array}$ \\
\hline $\mathbf{S}_{\mathbf{1}}$ & 2.967 & 24.806 & 27.768 \\
\hline $\mathbf{S}_{\mathbf{2}}$ & 2.966 & 22.166 & 25.026 \\
\hline $\mathbf{S}_{\mathbf{3}}$ & 2.665 & 15.65 & 18.31 \\
\hline $\mathbf{S}_{\mathbf{4}}$ & 2.377 & 11.738 & 14.106 \\
\hline $\mathbf{C D}(\mathbf{P} \leq \mathbf{0 . 0 5})$ & 0.034 & 1.748 & 1.758 \\
\hline
\end{tabular}

Table.6 Effect of spacing on the oil content of herbage per plant of Ocimum basilicum

\begin{tabular}{|c|c|c|}
\hline Treatments & Seed oil (ml/plant) & Herbage oil content (ml/plant) \\
\hline $\mathbf{S}_{\mathbf{1}}$ & 0.0105 & 0.532 \\
\hline $\mathbf{S}_{\mathbf{2}}$ & 0.0086 & 0.442 \\
\hline $\mathbf{S}_{\mathbf{3}}$ & 0.0065 & 0.282 \\
\hline $\mathbf{S}_{\mathbf{4}}$ & 0.0049 & 0.194 \\
\hline $\mathbf{C D}(\mathbf{P} \leq \mathbf{0 . 0 5})$ & 0.0017 & 0.032 \\
\hline
\end{tabular}

Plates
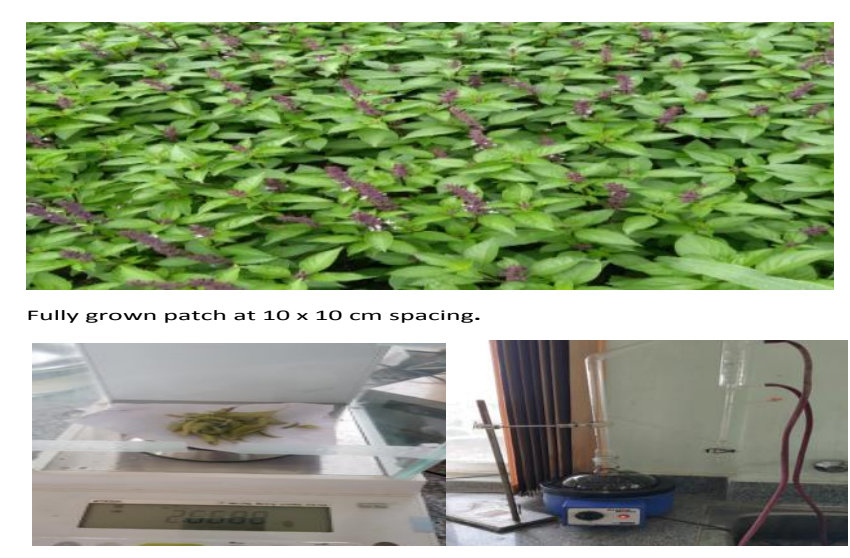

Leaf weight estimation.

Extraction of oil 
In light of the above mentioned facts, the present study on out planting performance of Ocimum basilicum in field plantation was undertaken to optimize the spacing required for achieving maximum yield and essential oil. All the seedlings showed a survival of 100 percent during first growing season, but there was a difference in their growth characteristics. Perusal of data from tables (15) reveal a significant influence of spacing on plant height, number of leaves, leaf fresh weight, leaf dry weight, total ground biomass and seed yield of Ocimum basilicum plants. Maximum values for all the yield parameters were recorded under $S_{1}(10 \mathrm{~cm} \times 10 \mathrm{~cm})$ whereas minimum were recorded for the higher spacing of $\mathrm{S}_{4}(10 \mathrm{~cm} \times 40 \mathrm{~cm})$. The reason may be that high density crops achieve canopy closure faster than thin ones and therefore intercept more radiation earlier, grow faster and compete with weeds better. Also, increasing plant density suppresses lateral branch growth thus leading to increase in plant height. The plant height was recorded maximum $(85.94 \mathrm{~cm})$ for the highest population density of $S_{1}(10 \mathrm{~cm} \times 10 \mathrm{~cm})$ and minimum plant height $(71.88 \mathrm{~cm})$ was recorded at least plant density of; $S_{4}(10 \times 40$ $\mathrm{cm})$.

The trend was same for other growth parameters viz., number of leaves per plant, leaf fresh weight (g/plant), leaf dry weight (g/plant), above ground biomass (g/plant), below ground biomass (g/plant) and total biomass (g/plant) which was also recorded higher at closest spacing of $S_{1}(10 \times 10 \mathrm{~cm})$ and minimum at a higher spacing of $S_{4}(10 \times$ $40 \mathrm{~cm}$ ). In the present study the plant was grown under complete rain fed conditions where its survival was 100 percent. The above ground biomass (g/plant) was recorded to be maximum in $S_{1}(10 \mathrm{~cm} \times 10 \mathrm{~cm})$ and minimum at a higher spacing $\mathrm{S}_{4}(10 \mathrm{~cm} \times 40$ $\mathrm{cm})$. The below ground biomass (g/plant) was recorded to be maximum in $S_{1}(10 \mathrm{~cm} \times 10$ $\mathrm{cm})$ and minimum at a higher spacing $\mathrm{S}_{4}(10$ $\mathrm{cm} \times 40 \mathrm{~cm})$. However the leaf area $\left(\mathrm{cm}^{2}\right)$ was recorded maximum $\left(3.018 \mathrm{~cm}^{2}\right)$ at a higher spacing $\mathrm{S}_{4}(10 \mathrm{~cm} \times 40 \mathrm{~cm})$ and minimum $\left(2.584 \mathrm{~cm}^{2}\right)$ under $S_{1}(10 \mathrm{~cm} \times 10$ $\mathrm{cm})$. The reason may be more space available for the leaves resulting in an increase in the leaf area. Similar results were found by Abbas (2014) who reported that basil with the density of 100 plants per $\mathrm{m}^{2}$ i.e., at $10 \mathrm{~cm} \times$ $10 \mathrm{~cm}$ had the highest height and yield in whole plant dry weight as compared to basil planted at a high spacing of 80, 60 and 40 plants per $\mathrm{m}^{2}$. Therefore, recommended cultivation of basil at density of 100 plants per $\mathrm{m}^{2}$ in order to obtain maximum dry weight.

Akbarinia et al., (2006) reported that plants in high densities compete for light, thus, it results in rising plant height. Our findings also demonstrated that plant height increases when density increased 25 to 100 plants per $\mathrm{m}^{2}$ i.e., from $10 \mathrm{~cm} \times 40 \mathrm{~cm}$ to $10 \mathrm{~cm} \times 10$ $\mathrm{cm}$. By increasing density from 25 to 100 plants per $\mathrm{m}^{2}$ i.e., from $10 \mathrm{~cm} \times 40 \mathrm{~cm}$ to 10 $\mathrm{cm} \times 10 \mathrm{~cm}$, dry weight will increase. Due to increased plant per unit of area, dry weight will increase in density of 100 plants per $\mathrm{m}^{2}$.

These findings confirm the study of Jalilavand et al., (2006), who reported an increase in the biomass with increases in plant density from 25 plants per $\mathrm{m}^{2}$ to 100 plants per $\mathrm{m}^{2}$. Increasing density results in raising leaf dry weight and whole plant dry weight in the unit area. This is also because in high densities there are more plants per unit area, it causes rising in leaf dry and whole plant dry weight totally.

\section{Observations recorded in the laboratory}

The seed weight of 1000 seeds was recorded on a digital balance. The average seed weight was recorded to be $1.76 \mathrm{~g}$. 
Germination percent of Ocimum basilicum $\mathrm{L}$ under lab, conditions

The germination percent of seeds was calculated in the laboratory of faculty of forestry Benhama, Ganderbal. 100 seeds per replication were placed petri plates replicated four times using double fold germination paperon in November, 2018 and were placed in seed germinator. Observations were recorded for 28 days. Seed germination started from the second day onwards and the germination was completed in 7 th days.

Effect of spacing on the seed and herbage oil content per plant of Ocimum basilicum L.

Results from the present study of Ocimum basilicum (Table 6) also indicate a significant effect of spacing on essential oil yield. An average oil content of $2 \mathrm{ml} / 100 \mathrm{~g}$ was recorded in the herbage under the highest plant density $S_{1}(10 \mathrm{~cm} \times 10 \mathrm{~cm})$ followed by an average oil content of $1.85 \mathrm{ml} / 100 \mathrm{~g}$ recorded in $S_{2}(10 \mathrm{~cm} \times 20 \mathrm{~cm})$ and an average oil content of $1.66 \mathrm{ml} / 100 \mathrm{~g}$ recorded in $S_{3}(10 \mathrm{~cm} \times 30 \mathrm{~cm})$. While as, the minimum average oil content of $1.51 \mathrm{ml} / 100$ $\mathrm{g}$ was recorded for the lowest plant density $\mathrm{S}_{4}$ $(10 \mathrm{~cm}$ x $40 \mathrm{~cm})$. Also an average oil content of $1 \mathrm{ml} / 100 \mathrm{~g}$ was recorded in the seeds under the highest plant density $S_{1}(10 \mathrm{~cm} \times 10 \mathrm{~cm})$ followed by an average oil content of 0.85 $\mathrm{ml} / 100 \mathrm{~g}$ recorded in $\mathrm{S}_{2}(10 \mathrm{~cm} \times 20 \mathrm{~cm})$ and an average oil content of $0.66 \mathrm{ml} / 100 \mathrm{~g}$ recorded in $\mathrm{S}_{3}(10 \mathrm{~cm} \times 30 \mathrm{~cm})$. While as, the minimum average oil content of $0.51 \mathrm{ml} / 100$ $\mathrm{g}$ was recorded for the lowest plant density $\mathrm{S}_{4}$ $(10 \mathrm{~cm} \times 40 \mathrm{~cm})$. The maximum essential oil yield from all parts of plants viz., seeds $(0.0105 \mathrm{ml} /$ plant $)$ and herbage $(0.532$ $\mathrm{ml} / \mathrm{plant})$ was recorded for $S_{1}(10 \mathrm{~cm} \times 10$ $\mathrm{cm})$ and minimum oil content from seeds $(0.0049 \mathrm{ml} / \mathrm{plant})$ and herbage $(0.194$ $\mathrm{ml} /$ plant) was recorded for the higher spacing
$S_{1}(10 \quad \mathrm{~cm} \quad \mathrm{x} \quad 40 \mathrm{~cm})$. Transplanting of seedlings was done in the month of July and harvesting was done in the month of October. Both these factors i.e., the effect of transplanting dates and development stage at harvest on the herb and oil yield were studied (Randhawa and Gill, 1995). The maximum herb and oil yield were measured when French basil seedlings were transplanted at the end of July. Later transplanting decreased the oil content of the leaves. These results can be understood according to the effects of temperature and day length (Putievsky, 1983).

In conclusion the propagation of Ocimum basilicum can be done by seeds. It is recommended that the spacing of $S_{1}(10 \mathrm{~cm} \times$ $10 \mathrm{~cm}$ ) should be followed to get better yield of crop and oil content.

\section{References}

Abbas, M. S. 2014. Assessment of density and cultivation type on growth and yield of two cultivars of basil (Ocimum basilicum L.). International Journal of Agronomy and Agricultural Research 5(1): 74-79.

Acimovic, M. G. 2013. The influence of fertilization on field of caraway, anise and coriander in organic agriculture. Journal of agricultural Sciences 58(2): 85-94

Akbarinia, A., Daneshian, J. and Mohammadbeigi, F. 2006. Effect of nitrogen fertilizers and density on yield of seed and essential oil in coriandrum. Iranian Journal of Medicinal and Aromatic Plants 34: 410-419.

Azizi, K. and Kahrizi, D. 2008. Effect of nitrogen levels, plant density and climate on yield quantity and quality in cumin (Cuminum cyminum L.) under the conditions of Iran. Asian Journal of Plant Sciences 7(8): 710-716.

Bora, K. S., Arora, S, and Shri, R. 2011. Role 
of Ocimum basilicum L. in prevention of ischemia and reperfusion-induced cerebral damage, and motor dysfunctions in mice brain. Journal of Ethnopharmacolgy 37: 1360-1365.

Jalilavand, H., Akbarinia, A., Khodabandeh, N. and Habibi D. 2006. Effect of nitrogen fertilizers and plant density on yield of oil and mucilage in Ocimum seeds. Iranian Journal of Agronomy Breeding 2: 11-27.

Javanmardi, J., Khaleghi, A., Kashi, A., Bais, H. P, and Vivanco, J. M. 2002. Chemical Characterization of Basil (Ocimum basilicum L.) Found in Local Accessions and Used in Traditional Medicines in Iran. Journal of Agriculture and Food Chemistry 50: 5878-5883.

Khazaie, H. R., Nadjafi, F. and Banyan, M. 2007. Effect of irrigation frequency and planting density on herbage biomass and oil production of thyme (Thymus Vulgaris) and hyssop (Hyssop officinalis). Industrial Crops and Products Journal 27: 315-321.

Paton, A. and Putievsky, E. 1996. Taxonomic problems 433 and cytotaxonomic relationships between and within varieties of Ocimum basilicum and related species (Labiatae). Kew Bulletin 14: 509-524.

Putievsky, E. 1983. Temperature and day length influences on the growth and germination of sweet basil and oregano. The Journal of Horticultural Science and Biotechnology 58: 583587.
Randhawa, G. S. and Gill, B. S. 1995. Transplanting dates, harvesting stage, and yields of French basil (Ocimun basilicum L.). Journal of Herbs, Spices \& Medicinal Plants 3: 45-56.

Sadeghi, S., Rahnavard, A. and Ashrafi, Z. Y. 2009. The effect of plant-density and sowing-date on yield of Basil (Ocimum basilicum L.) in Iran. Journal of Agricultural Technology 5(2): 413422.

Venâncio, A. M., Onofre, A. S., Lira, A. F., Alves, P. B., Blank, A. F., Antoniolli, A. R., Marchioro, M., Estevam, C. S, and Araujo, B. S. 2011. Chemical composition, acute toxicity, and antinociceptive activity of the essential oil of a plant breeding cultivar of basil (Ocimum basilicum L.). Planta Medica 77: 825-829.

Werker, E., Putievsky, E., Ravid, U., Dudai, N. and Katzir, I. 1993. Glandular hairs and essential oil in developing leaves of Ocinun basilicun L. (Lamiaceae). Annual Botany 71: 43-50.

Yayasinghe, C., Gotoh, N., Aoki, T. and Wada, S. 2003. Phenolics composition and antioxidant activity of sweet basil (Ocimum basilicum L.). Journal of Agricultural and Food Chemistry 51: 4442-4449.

Zamfirache, M. M., Burzo, I., Olteanu, Z., Dunca, S., Surdu, S., Truta, E., Stefan, M. and Rosu, C. M. 2008. Research regarding the volatile oils composition for Ocimum basilicum L. and possible phytotherapeutic effects. Genetic and Molecular Biology 9: 35-40.

\section{How to cite this article:}

Huzaifa Majeed, G. M. Bhat, M. A. Islam, T. A. Rather, F. A. Shah khan, Rayees A. Bhat and Nida Rafiq 2020. Effect of Spacing on Different Growth Parameters and Oil Content of Ocimum basilicum L under Temperate Conditions of Kashmir Valley. Int.J.Curr.Microbiol.App.Sci. 9(10): 995-1002. doi: https://doi.org/10.20546/ijcmas.2020.910.119 